EESTI NSV TEADUSTE AKADEEMIA TOIMETISED. 31. KOIDE GEOLOOGIA. 1982, NR. 2

ИЗВЕСТИЯ АКАДЕМИИ НАУК ЭСТОНСКОН ССР. ТОМ 31 ГЕОЛОГИЯ, 1982, Ni 2

\title{
СОВРЕМЕННОЕ СОСТОЯНИЕ МИРОВЫХ РЕСУРСОВ ГОРЮЧИХ СЛАНЦЕВ И ПРОЕКТЫ ИХ ИСПОЛЬЗОВАНИЯ
}

Прогнозы роста численности населения в глобальном масштабе и потребности в энергии, с одной стороны, а также ограниченность ресурсов нефти, с другой, обращают все возрастающее внимание научных, промышленных и политических кругов ведущих государств мира на необходимость получения альтернативного жидкого топлива, особенно моторного топлива из горючих сланцев. Например, по прогнозам ИИАСА *, изложенным в отчете «Энергетика в ограниченном мире» ['], заметное ппотребление искусственного жидкого топлива (ИЖТ) из горючих сланцев, битуминозных песков и тяжелых нефтей начинается в 1985-1990 гг. и к 2030 т. достигнет 1,3-2,4 млрд. $т$ условной нефти в год. Это составит около $25-30 \%$ всего количества потребляемого жидкого топлива в мире, включая ИЖТ из углей. В последнее десятилетие во многих странах ведутся обширные исследования по выявлению запасов горючих сланцев, разработке опытных установок и промышленных проектов их переработки и использования в народном хозяйстве. Итоги этих работ еще недостаточно отражены в литературе.

Ниже изложены сведения о современных мировых ресурсах горючих сланцев и рассмотрены состояние и ближайшие перспективы использования этих сланцев в качестве сырья для получения ИЖТ за рубежом.

\section{Мировые запасы горючих сланцев}

Известные на 1980 г. мировые запасы горючих сланцев были рассмотрены на 6-й конференции ИИАСА, посвященной проблеме «Мировые ресурсы горючих сланцев и их возможное использование», в т. Голдене (США) в 1981 г. По докладу Дэлае (ИИАСА) $\left[{ }^{2}\right]$ и другим источникам $\left[{ }^{3-7}\right]$, известные на 1980 г. мировые запасы эквивалентной нефти (сланцевой смолы), выделяемой пиролизом горючего сланца стандартным методом в алюминиевой реторте Фишера при температуре $500^{\circ} \mathrm{C}$, составляют около 630 млрд. т, что значительно превышает известные мировые резервы нефти, которые можно добыть с помощью известной техники (280 млрд. т).

Приведенные в табл. 1 данные по запасам в различных странах мира существенно различаются по степени разведанности и качеству исходного сланца. Например, запасы США (280 млрд. $T$ эквивалентной нефти) представлены в основном геологически хорошо разведанным ресурсом эоценовых сланцев формации Грин-Ривер, расположенной в штатах Колорадо, Юта и Вайоминг. Выход смолы грин-риверских сланцев по методу Фишера не менее $15-25$ галлонов на 1 шорт тон (не менее 5,5-9,1 вес.\%). Запас сланцев в США еще на порядок выше и

* Международный институт прикладного системного анализа в Лаксенбурге (Австрия). 


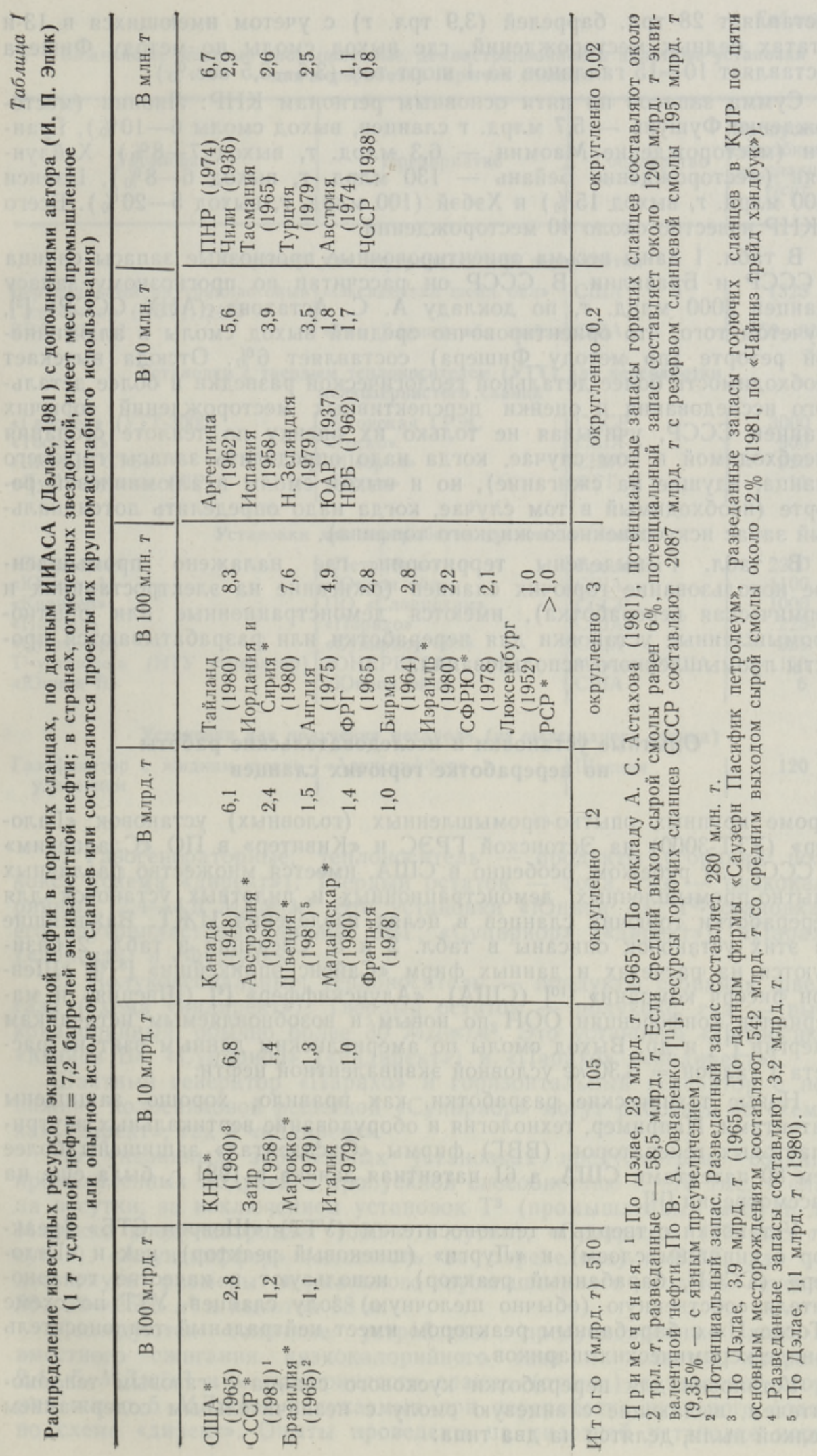


составляет 28 трл. баррелей (3,9 трл. т) с учетом имеющихся в 13-и штатах бедных месторождений, где выход смолы по методу Фишера составляет $10-15$ галлонов на 1 шорт тон $(3,6-5,5$ вес. $\%)$.

Сумма запасов по пяти основным регионам КНР: Ляонин (месторождение Фушунь - 5,7 млрд. т сланцев, выход смолы 6-10\%), Гуандун (месторождение Маомин - 6,3 млрд. т, выход $7-8 \%$ ), Хейлунцзян (месторождение Бейань - 130 млрд. $т$, выход 6-8\%), Цзянси (300 млрд. т, выход 15\%) и Хэбэй (100 млрд. т, выход 5-20\%). Всего в КНР известно около 40 месторождений.

В табл. 1 даны весьма ориентировочные прогнозные запасы сланца в СССР и Бразилии. В СССР он рассчитан по прогнозному запасу сланцев 2000 млрд. T, по докладу А. С. Астахова (АНХ СССР) [3], с учетом того, что ориентировочно оредний выход смолы в алюминиевой реторте (по методу Фишера) составляет 6\%. Отсюда вытекает необходимость более детальной геологической разведки и более детального исследования и оценки перспективных месторождений горючих сланцев СССР, учитывая не только их оценку по теплоте сгорания (необходимой в том случае, когда надо определить запасы горючего сланца, идущие на сжигание), но и выход смолы в алюминиевой реторте (необходимый в том случае, когда надо определить потенциальный запас искусственного жидкого топлива).

В табл. 1 выделены территории, где налажено промышленное использование горючих сланцев (сжигание на электростанциях и термическая переработка), имеются демонстрационные или опытнопромышленные установки для переработки или разрабатываются проекты промышленного использования.

\section{Опытные установки и исследовательские работы по переработке горючих сланцев}

Кроме крупных опытно-промышленных (головных) установок «Галотер» (УТТ-3000) на Эстонской ГРЭС и «Кивитер» в ПО «Сланцехим» в СССР, за рубежом, особенно в США, имеется множество различных опытно-промышленных, демонстрационных и пилотных установок для переработки горючих сланцев в целях извлечения ИЖТ. Важнейшие из этих установок описаны в табл. 2 и 3. Сведения в табл. 2 базируются на расчетах и данных фирм «Сайенс эпликейшн» [8,9], «Шеврон рисерч компани» $\left.{ }^{10}\right]$ (США), «Алунскиффер» $\left[{ }^{4}\right]$ (Швеция) и материалов конференции ООН по новым и возобновляемым источникам энергии [1"] и др. Выход смолы по американским данным взят из расчета 1 галлон $=3,30$ ке условной эквивалентной нефти.

Новые технические разработки, как правило, хорошо защищены патентами. Например, технология и оборудование вертикальных внутрипластовых генераторов (ВВГ) фирмы «Оксидентал» защищены более чем 80 патентами США, а 61 патентная заявка в 1981 г. была еще на рассмотрении $\left[{ }^{12}\right]$.

Установки с твердым теплоносителем (УТТ) «Шеврон СТБ» (реактор с кипящим слоем) и «Лурги» (шнековый реактор), как и «Галотер» (СССР, барабанный реактор), используют в качестве теплоносителя собственную (обычно щелочную) золу сланцев. УТТ по схеме «Тоско IІ» с барабанным реактором имеет нейтральный теплоноситель в виде керамических шариков.

Установки для переработки кускового сланца с газовым теплоносителем, выдающие сланцевую смолу с незначительным содержанием мелкой пыли, делятся на два типа; 
Важнейшие опытные промышленные, демонстрационные и пилотные установки для переработки горючих сланцев

\begin{tabular}{c|c|c|c}
\hline Установка & Предприятие & Государство & $\begin{array}{l}\text { Пропускная } \\
\text { способность } \\
\text { по сланцу, } \\
\text { т/сут }\end{array}$ \\
\hline
\end{tabular}

Установки для внутрипластовой переработки

Вертикальный внутрипластовый «Оксидентал шейл ойл» /США

генератор (ВВГ), $2425 \mu^{2}$
ВВГ, $333 \mu^{2}$

Установки с твердым теплоносителем (УТT) для переработки мелкозернистого сланца

«Галотер» (УТТ-3000)

«Тоско II»

«Шеврон СТБ»

«Лурги-Рургаз»

Эстонокая ГРЭС
«Тоско»
«Шеврон»
«Лурги»

СССР
США
США
ФРГ

3000

900

320

11
«Петросикс» «Юнион А» «Кивитер» «Парахо»

«Супирнор» $\mathrm{T}^{3}$-установка «Юнион Б»

\section{Установки для переработки кускового сланца}

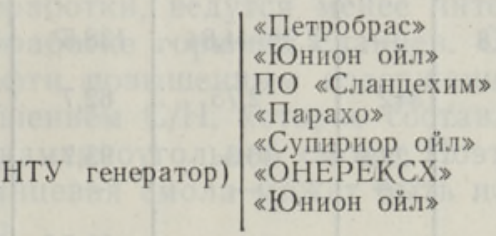

\begin{tabular}{|l} 
Бразилия \\
США \\
СССР \\
США \\
США \\
Марокко/США \\
США
\end{tabular}

\section{Установки для получения метанола (из пылевидного сланца)}

Газификатор с жидкнм шлако-|«Алунскиффер» | Швеция | удалением

1. Газогенераторные; теплоноситель - продукты сгорания полукокса (схема «директ»). Твердый остаток - зола, газ - низкокало-

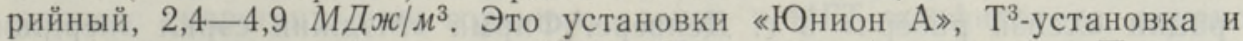
его внутрипластовый аналог ВВГ, «Супириор» («директ»), «Парахо» («директ») и «Фушунь».

2. Полукоксовальные; теплоноситель - продукты сгорания швельгаза (схема «индирект»). Твердый остаток - полукокс, газ - высо-

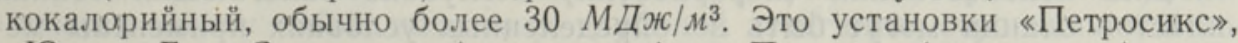
«Юнион Б», «Супириор» («индирект») и «Парахо» («индирект»).

Шахтный генератор «Парахо» и горизонтальный генератор с подвижной колосниковой решеткой «Супириор» могут работать по схемам как «директ», так и «индирект».

На указанных зарубежных установках предусмотрено создание промышленных модулей с пропускной способностью 7-10 тыс. $т$ сланца в сутки, за исключением установок $\mathrm{T}^{3}$ (промышленный модуль для Марокко предусматривает 1000 т в сутки), «Супириор» (27 тыс. $T$ в сутки), «Алунскиффер» (мощность не определена) и ВВГ, где уже достигнуты размеры нормального промышленного модуля сечением $50 \times 50=2500 \mu^{2}$ и высотой $88 \mu$.

Исследуются топочные устройства, предусмотренные для совместного сжигания низкокалорийного газа с теплотой сгорания

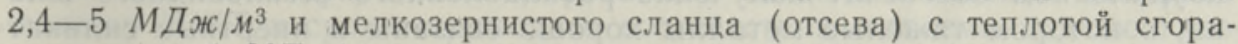
ния около $5 \mathrm{MДж/ \kappa 2,} \mathrm{получаемых} \mathrm{при} \mathrm{переработке} \mathrm{кускового} \mathrm{сланца}$ по схеме «директ». Опыты проведены на пилотной установке корпо- 
Основные характеристики зарубежных установок переработки горючих сланцев (применительно к колорадским сланцам)

\begin{tabular}{|c|c|c|c|c|c|c|}
\hline $\begin{array}{c}\text { Установка } \\
\text { (см. табл. 2) }\end{array}$ & $\begin{array}{c}\text { Размеры } \\
\text { кусков } \\
\text { сланца, } \\
\text { м. }\end{array}$ & $\begin{array}{c}\text { Выход } \\
\text { смолы по } \\
\text { Фишеру, } \\
\text { вес. \% }\end{array}$ & $\begin{array}{c}\text { Выход } \\
\text { газа, } \\
M^{3} / T\end{array}$ & 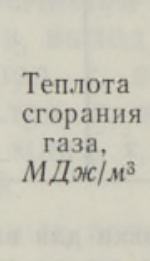 & $\begin{array}{l}\text { Потреб- } \\
\text { ность в } \\
\text { электро- } \\
\text { энергин, } \\
\text { включая } \\
\text { добычу } \\
\text { сланца, } \\
\kappa B T \cdot ч / T\end{array}$ & $\begin{array}{c}\text { Характеристика } \\
\text { отработанного } \\
\text { сланца }\end{array}$ \\
\hline $\mathrm{BB} \Gamma$ & - & 10,0 & 504 & 3,16 & 39,3 & Зола внутри \\
\hline «Тоско II» & $0-13$ & 11,1 & 36,5 & 36,0 & 75,7 & $\begin{array}{c}\text { Полукокс, C } \\
\text { около } 5 \%\end{array}$ \\
\hline «Шеврон СТБ» & $0-6,4$ & $4,2-11,4$ & - & - & & $\begin{array}{l}\text { Зола, С } \\
0,3-0,7 \%\end{array}$ \\
\hline $\begin{array}{l}\text { «Лурги-Рургаз» } \\
\text { «етросикс»1 }\end{array}$ & $\begin{array}{r}0-6,4 \\
0-152 \\
64-25\end{array}$ & $\underline{11,1}$ & $\frac{23,8}{-}$ & $\stackrel{23,8}{-}$ & $\begin{array}{l}80,9 \\
64,3\end{array}$ & $\begin{array}{l}\text { Зола, С } 0,2 \% \\
\text { Полукокс }\end{array}$ \\
\hline $\begin{array}{c}\text { Парахо» («ди- } \\
\text { рект») }\end{array}$ & $9,5-76$ & 10,7 & 228 & 4,35 & 59,1 & Зола, С 0,2\% \\
\hline $\begin{array}{l}\text { «арахо» («ин- } \\
\text { директ») }\end{array}$ & $9,5-76$ & 10,7 & 15,9 & 32,9 & 64,6 & $\begin{array}{c}\text { Полукокс, C } \\
\text { более } 2 \%\end{array}$ \\
\hline $\begin{array}{l}\text { «Супирнор» } \\
\text { («директ») }\end{array}$ & $6,4-102$ & $7-14,8$ & - & $2,98-4,84$ & 138,5 & Зола \\
\hline $\begin{array}{r}\mathrm{T}^{3} \text { (сланец из } \\
\text { штата Юта) }\end{array}$ & $13-152$ & 9,3 & 342 & 2,75 & 62,7 & Зола \\
\hline $\begin{array}{l}\text { «Юнион Б» } \\
\text { «ушунь» }\end{array}$ & $\begin{array}{l}3,2-50 \\
9,5-70\end{array}$ & 13,3 & 23,8 & 36,5 & 95,7 & Полукокс \\
\hline $\begin{array}{l}\text { 《ФушНР) } \\
\text { «Алунскиффер» }\end{array}$ & $0-0,2$ & $4-6$ & & - & $33,7^{3}$ & $\begin{array}{l}\text { Гранулирован- } \\
\text { ный инертный } \\
\text { шлак }\end{array}$ \\
\hline
\end{tabular}

При ме чания. ${ }^{1}$ Сланец месторождения Ирати (Бразилия); выходы смолы $7 \%$ и высококалорийного газа $18,2 \mathrm{~m}^{3} / T$.

2 Сланец месторождения Нэрке (Швеция).

3 Синтез газа, без добычи сланца.

рации «Хейзн рисерч» в г. Денвере. Фирма «Мэджик сэркл энерджи корпорейшн» предусматривает создание соответствующего энергоблока мощностью $150 \mathrm{MBT}$ для производства электроэнергии и с выходом технологического пара $200 \mathrm{~T} / 4$ [ $\left.{ }^{9}\right]$.

Для использования (переработки) неглубоко залегающих тонких пластов сланца могут быть в определенных условиях применены методы т. н. тотальной или полностью внутрипластовой переработки. Такие методы позволяют обойтись без подземных горно-выемочных работ, применяя бурение и взрывы внутри пласта. На 1981-1982 гг. корпорации «Геокинетикс» и «Иквити ойл» запланировали провести соответствующие опыты крупного масштаба в штатах Юта и Колорадо («Геокинетикс» на производство $140 \mathrm{~T}$ ИЖТ в сутки).

С точки зрения использования высокозернистых горючих сланцев и сланцев, содержащих тяжелые металлы, особый интерес представляют опыты фирмы «Алунскиффер» (Швеция) по получению из бедных сланцев ордовикского месторождения Нэрке (выход смолы по Фишеру 4-6\%) метанола и серы, причем прогнозная стоимость $1 T$ метанола около 160-200 американских долларов. Газификатор с жидким шлакоудалением обеспечит получение расплавленного стекловидного шлака, в котором тяжелые металлы хорошо связаны в инертные силикатные соединения и поэтому не подвержены выщелачиванию в золоотвалах [4]. 
Объем научно-исследовательских и опытных работ в области переработки горючих сланцев, проводимых за последнее десятилетие ведущими нефтяными компаниями США, составляет более 400 млн. американских долларов даже без учета значительных расходов на аренду земляных участков [6]. Например, для сооружения шести опытных ВВГ на участке Лоуган Уаш компания «Оксидентал» израсходовала 100 млн. долларов и намерена расходовать еще 65 млн. долларов на ВВГ № 7 и 8. «Юнион ойл компани оф Калифорния» вложила в разработку технологии 65-70 млн. долларов. «Колони девелопмент оперейшн» - совместное предприятие компаний «Экссон» и «Тоско» израсходовала 75 млн. долларов. «Супириор ойл» вложила в это дело 20 млн. долларов. «Парахо девелопмент корпорейшн» с участием 17 нефтяных фирм выплатила 17 млн. долларов. Часть этих работ финансировалась Министерством энергетики и Министерством обороны США. Следует отметить, что большие участки на Колорадском сланцевом месторождении и в штате Юта выделены в резерв военноморското флота США.

Хотя сланцевая промышленность еще не располагает коммерческим продуктом, тем не менее нефтяные фирмы США уже конкурируют друг с другом в области исследований и разработок [ $\left.{ }^{6}\right]$. Работы по переработке сырой сланцевой смолы, полученной в результате термической переработки, ведутся менее интенсивно, чем работы по термической переработке горючих сланцев. Сланцевая смола отличается от обычной нефти повышенным содержанием азота и кислорода и весовым соотношением $\mathrm{C} / \mathrm{H}$, которое составляет $7-9$ против 6-7 в нефти и 10-16 в каменноугольной смоле. Поэтому без предварительной переработки сланцевая смола может быть использована только как котельное топливо.

В генеральной линии зарубежных проектов предусмотрена гидрогенизация смолы с удалением азота и мышьяка, которые отравляют катализаторы нефтеперерабатывающих заводов. После гидрогенизации сланцевая смола становится сырьевым продуктом для обычных нефтеперерабатывающих заводов и позволяет получать высококачественное моторное (в основном дизельное и авиационное) топливо.

Институтом технологии газа (Чикаго, США) разработан также процесс гидрогенизации горючего сланца в ИГТ-газификаторе, однако предполагают, что установка еще не будет достаточно отработана для применения в коммерческих проектах 80 -х годов.

На обширной территории СССР имеются месторождения горючих сланцев всех геологических периодов $\left[{ }^{13}\right]$. Эти месторождения отличаются между собой, например, глубиной залегания, строением и мощностью сланцевых пластов, выходом смолы и теплотой сгорания сланца, его механическими свойствами, характером и составом керогена, свойствами минеральной части, содержанием серы и тяжелых металлов. Поэтому богатый опыт по использованию кукерситов Прибалтийского бассейна в СССР весьма важно дополнить опытом переработки сланцев в других странах мира.

\section{Зарубежные проекты извлечения ИЖТ из горючих сланцев}

На основе данных из отмеченных выше источников литературы, а также $\left[{ }^{14-19}\right]$ в табл. 4 приведены типы и ориентировочные мощности технологических модулей, запланированные мощности заводов по производству ИЖТ и сроки их ввода в соответствии с восемнадцатью главными проектами сооружения крупных коммерческих сланцеперерабатывающих предприятий в Австралии, Бразилии, на Мадагаскаре, 


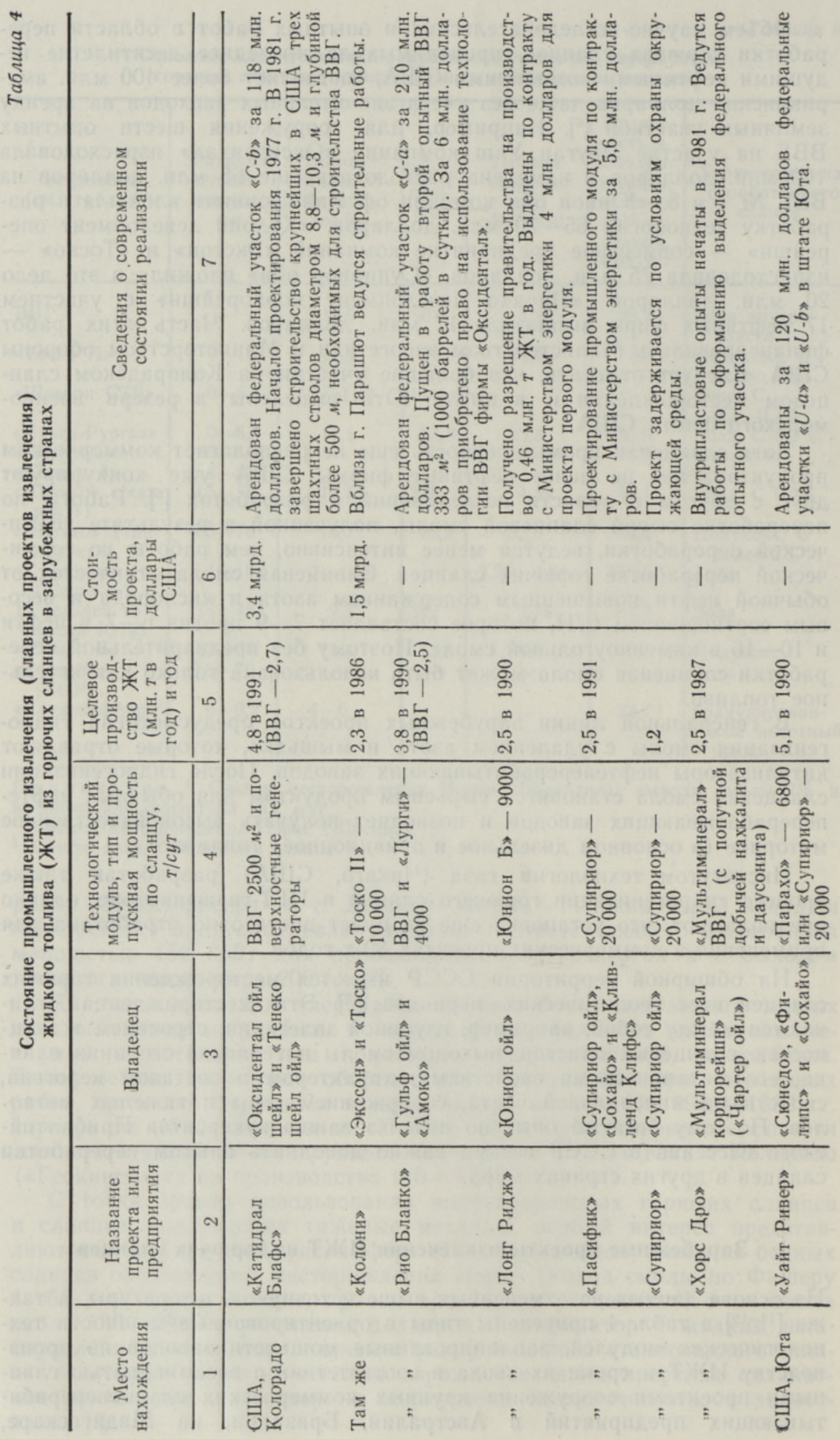


в Марокко, США, СФРЮ и Швеции и мощности двух действующих в КНР сланцеперерабатывающих заводов.*

Реализация указанных в табл. 4 проектов во второй половине $90-\mathbf{x}$ годов позволит достичь суммарного производства ИЖТ из горючих сланцев $50-60$ млн. $T$ в год. В настоящее время годовое производство ИЖТ из горючих сланцев (сланцевой смолы) в мире составляет около 1,1 млн. $T$, в том числе 0,8 в СССР. По проектам (табл. 4) к 1985 г. производство ИЖТ достигнет $7-8$ млн. $т$ в год (проекты «Катидрал Блафс», «Колони», «Рио Бланко», «Лонг Ридж», «Хорс Дро», «Уайт Ривер», «Парахо Ют» в США, «Петробрас» в Бразилии, «Фушунь» и «Маомин» в КНР и «Бемоланга» на Мадагаскаре), а к 1990 г. составит уже $30-35$ млн. $T$ в год (в том числе в США $23,5-28$ млн. $T$ в год).

Хотя проекты, приведенные в табл. 4, не единственные, подлежащие внедрению в 1990-1995 гг., прогнозы ИИАСА ['] по извлечению ИЖТ из горючих сланцев, битуминозных песков и тяжелых нефтей (в 1990 г. 0,3 млрд. $T$ в год и в 2000 г. $0,6-0,9$ млрд. $T$ в год) кажутся пока преувеличенными. Конечно, если доля сланцев в этих прогнозах составит только $10-15 \%$, то преувеличения нет. В другую сторону склоняется прогноз, представленный К. Матсуй $\left[{ }^{20}\right]$, согласно которому извлечение ИЖТ из сланцев в 1990 г. во всем мире составит 5-30, а в 2000 г. $30-75$ млн. $T$, а из битуминозных песков соответственно в 1990 г. $20-40$, а в 2000 г. $40-100$ млн. $T$.

Особый интерес представляют варианты (сценарии) освоения крупнейшего в США и хорошо изученного месторождения Пианс (Пайсенс) Крик формации Грин-Ривер на северо-западе штата Колорадо $\left[{ }^{21-24}\right]$. Имеются 4 варианта с многолетней перспективой $\left[{ }^{21}\right]$ (табл. 5).

Таблица 5

Варианты развития производства ИЖТ из горючих сланцев в штате Колорадо (США), млн. т/год

\begin{tabular}{l|c|c|c|c|c}
\hline \multicolumn{1}{c|}{ Сценарий } & 1981 & 1985 & 1990 & 1995 & 2000 \\
\hline Минимальный & 0 & 0,8 & 12 & 16 & 20 \\
Средний & 0 & 0,8 & 13 & 29 & 46 \\
Высокнй & 0 & 0,8 & 20 & 56 & 94 \\
Экстремальный & 0 & 0,8 & 22 & 83 & 203 \\
По известным проектам (табл. 4) & 0 & 4,3 & $17-22$ & $20-28$ &
\end{tabular}

В качестве «стандартного» завода для Колорадо и Юта рассматривается предприятие (шахта и завод составляют одно целое), производительность которого 2,5 млн. $т$ ИЖТ в год (это видно также из табл. 4), персонал около 2800 человек, потребляемая мощность около 200 МВт. На строительство комплекса (в среднем 3 млрд. долларов) предусмотрено 5 лет, выпуск продукции через 4 года после начала строительства, достижение полной мощности по переработке ожидается на третьем году работы. Энергоснабжение базируется в основном на угольных электростанциях, так как вблизи сланцевого бассейна Пианс (Пайсенс) Крик имеются богатые месторождения битуминозных

* По данным австралийского горного журнала (за 12 август 1981) на разлнчных стадиях изучения н освоения во всем мире находятся 37 процессов или проектов, связанных с добычей ИЖТ из сланцев. 
углей верхнего мелового пернода (формации Мезаверде), пригодных для опытных разработок. Транспортировка продукции предусмотрена трубопроводом: ИЖТ - на нефтеперерабатывающие заводы, а высококалорийный газ - потребителям.

По проектам суммарная мощность сланцеперерабатывающих заводов (табл. 4), для которых определена технология переработки, составляет 52 млн. 7 в год. Из этого с помощью ВВГ получают 9 млн. $T$ в год, или $17 \%$, с помощью УТТ - около 8 млн. т в год, или $15 \%$ (в том числе около 5 млн. т/год на установках «Тоско II»). Основное количество $(68 \%)$ получают путем переработки кускового сланца в поверхностных генераторах, снабженных газовым теплоносителем, по схемам «директ» и «индирект». ВВГ и схемы «директ» для переработки кускового сланца предусматривают наименьшее потребление технологической воды, что является их существенным преимуществом $\left(0,44-1,8 \boldsymbol{M}^{3} / T\right.$ против $4,9-5,2$ на УТТ). Бедный (низкокалорийный) газ, получаемый на ВВГ и установках со схемой «директ», предусмотрено использовать в качестве энергетического топлива для нужд предприятия; разрабатываются методы совместного сжигания бедного газа и мелкозернистого сланца в кипящем слое для проекта «Коттонвуд Уаш», возможно, также и для проекта «Катидрал Блафс» [].

С точки зрения баланса моторных топлив представляет интерес также прямое сжигание горючих сланцев в тех полупиковых электростанциях, которые обычно вынуждены использовать нефтяное топливо, легче перерабатываемое в топливо моторных видов, чем сланцевая смола. Например, в Эстонской ССР в настоящее время на электростанциях сжигается 28 млн. $T$ сланца в год, что высвобождает для других целей более 5 млн. т/год эквивалентной нефти. В настоящее время планируется сооружение еще одной полупиковой ТЭС в Эстонской ССР мощностью блоков $500 \mathrm{MBT}$ каждый. Мощная электростанция (первая очередь $990 \mathrm{MBT}$ ) сооружается в РСР на базе сланцев месторождения Анина [ $\left.{ }^{27}\right]$. Проекты сооружения (с участием СССР [25]) сланцевых ТЭС в Марокко составляют 1000 МВT, а в Иордании 300-400 МВт. Возможно, что прямое сжигание сланцев используется также на предприятиях КНР $[11,26]$. Общее количество сжигаемых для производства электрической энергии сланцев к концу 90-х годов может достичь $70-100$ млн. $T$ в год.

Небольшая мощность установок для переработки мелкозернистого сланца (УТТ составляют только 15\%) может быть обусловлена механическими свойствами сланцев и структурой сланцевых лластов (небольшой выход мелочи при их выемке и дроблении). Этот вопрос требует специального изучения.

В табл. 6 приведены ориентировочные данные о выходе смолы и толщине пластов сланца по важнейшим проектам использования. Основная масса сланцевой смолы извлекается из относительно бедных сланцев с выходом смолы 7-10 вес.\%. Низкое качество сланцев, как правило, компенсируется наличием сверхмощных пластов. Добыча и переработка сланцев из маломощной пачки имеют место только в Прибалтийском бассейне СССР (толщина промышленной пачки $2,2-2,5$ м). В Прибалтийском бассейне это оправдано высоким качеством сланца (выход смолы 13-15, после обогащения 18-20\%). Данные, приведенные в табл. 6, указывают на необходимость усиления геологической разведки по выявлению новых перспективных месторождений горючих сланцев в СССР.

В зарубежных проектах по переработке горючнх сланцев особое внимание уделяется вопросам охраны окружающей ореды и социальноэкономическим проблемам местности. Например, в США при отводе участков под строительство заводов и для получения разрешения на 
Таблица 6

Приближенные характеристики сланцев в проектах

\begin{tabular}{|c|c|c|c|}
\hline \multirow{2}{*}{$\begin{array}{l}\text { Выход } \\
\text { смолы, } \\
\text { вес. } \%\end{array}$} & \multirow{2}{*}{$\begin{array}{c}\text { Толщина } \\
\text { рабочего пласта, } \\
M\end{array}$} & \multicolumn{2}{|c|}{$\begin{array}{l}\text { Суммарное количество } \\
\text { используемых сланцев }\end{array}$} \\
\hline & & млн. $T / 20 \partial$ & $\%$ \\
\hline $13-17$ & $\begin{array}{l}2-3 \\
10-30 \\
70-300\end{array}$ & $\begin{array}{r}50 \\
\text { нет } \\
\text { нет }\end{array}$ & 6 \\
\hline $10-13$ & $\begin{array}{l}2-3 \\
10-30 \\
70-300\end{array}$ & $\begin{array}{l}\text { нет } \\
190 \\
\text { нет }\end{array}$ & 23 \\
\hline $7-10$ & $\begin{array}{l}2-3 \\
10-30 \\
70-300\end{array}$ & $\begin{array}{l}\text { нет } \\
160 \\
300\end{array}$ & 54 \\
\hline $4-7$ & $\begin{array}{l}2-3 \\
10-30 \\
70-300\end{array}$ & $\begin{array}{r}\text { нет } \\
70 \\
70 \\
\end{array}$ & 17 \\
\hline $\begin{array}{l}\text { I т о о } \\
\text { в том ч1 } \\
\text { электр }\end{array}$ & $\begin{array}{l}\text { сжигаемое на } \\
\text { нциях }\end{array}$ & $\begin{array}{r}840 \\
80\end{array}$ & $\begin{array}{r}100 \\
\sim 10\end{array}$ \\
\hline
\end{tabular}

выпуск коммерческой продукции ИЖТ из сланцев, компания-заявитель должна доказать предварительными проектами, что не будут нарушены требования и стандарты по защите окружающей среды (обычно на это уходит не менее четырех лет). Основные нарушения правил охраны окружающей среды заключаются в сильном загрязнении воз. духа пылью при добыче сланцев и свалке твердого остатка отработанных сланцев, а также в выщелачивании вредных компонентов из отвалов отработанного сланца и сбросе их в природные водоемы.

В проектах, предусматривающих внутрипластовую разработку (ВВГ), зола остается внутри пласта, но все же не исключено выщелачивание вредных компонентов. Пока применяются только меры уплотнения (цементации) нижней части (дна) ВВГ, где скапливается конденсат. Технология переработки на ВВГ по схеме фирмы «Мультиминерал» предусматривает специальное выщелачивание кальцинированной соды и других товарных компонентов из отработанного ВВГ сланца. Опыты начаты в 1981 г. При полной мощности завода «Хорс Дро» ожидаемый выход соды составляет около 20 тыс. т в сутки.

В проектах по открытой добыче сланцев предусмотрены свалка сухой золы в отработанное пространство разреза и рекультивация поверхности. Например, в одном из крупнейших в мире карьеров «Рандл» (Австралия), максимальная мощность которого около 0,4 млн. $т$ сланца в сутки (вместе с породой 0,8-1,0 млн. $T$ в сутки), в первые годы проектом предусмотрена плоская свалка золы и породы (высотой до 50 м) на площади рядом с разрезом. По достижению дна сланцевого пласта на глубине 300-400 м, породу и отработанный сланец сваливают в карьер. Для транспортировки предусмотрены ленточные конвейеры шириной 1,8 м, общая протяженность которых на территории предприятия составляет около 50 км. Примерно такая-же схема укладки породы вместе со сланцевой золой, но меньшего масштаба (160 тыс. т сланца в сутки) предусмотрена в проекте для Марокко.

Во многих проектах (в Колорадо и Юта) по поверхностной переработке отработанный сланец (полукокс или золу) сваливают конвейерами или самосвалами в глубокие каньоны, которые превращаются в изолированные от вод (водонепроницаемые) «бассейны» (например, 
проекты «Колони», «С̆нд Уаш», «Парахо Ют» и др.). Поверхность отвала покрывают горной породой и постепенно озеленяют. Пересеченная ущельями горная местность и сухой климат (около 350 мм в год осадков) благоприятствуют такому способу удаления остатков.

Для предотвращения запыления (особенно при переработке мелкозернистого сланца в УТТ) изучается оптимальная влажность отработанного сланца. Например, в проекте «Колони» оптимальной принята влажность $12 \%$.

\section{Экономические аспекты}

Большое количество крупных зарубежных проектов по извлечению ИЖТ и горючих сланцев, а также начало их реализации обещают явную экономическую перспективу для этой новой крупнейшей отрасли промышленности. В США ориентировочная стоимость ИЖТ из горючих сланцев колеблется в широких пределах: от 110 до 220 долларов за тонну (15-30 долларов за баррель) в зависимости от применяемой технологии и оптимизма авторов технико-экономических расчетов. Но даже при больших непредвиденных затратах на строительство заводов и на инфраструктуру предполагают, что ИЖТ из сланцев будет стоить на 10-15 долларов за баррель меньше, чем ИЖТ из каменного угля [ $\left.{ }^{6}\right]$. За последние годы технико-экономические расчеты по переработке горючих сланцев стали значительно точнее $\left[{ }^{12,} 19,21,28\right]$.

Например, сметная стоимость предприятия «Катидрал Блафс» (4,77 млн. т ИЖТ в год) по ценам 1978 г. была 1,7 млрд. долларов [ $\left.{ }^{6}\right]$, а по ценам 1980 г. уже 3 млрд. долларов [12]. Стоимость предприятия «Колони» (2,33 млн. $T$ ИЖТ в год) в ценах 1977 г. составляла 1,05 млрд. долларов и прямые расходы - 34,5-39,5 долларов на тонну ИЖТ, а в 1980 г. - соответственно 1,5 млрд. долларов и 72 доллара на тонну ИЖТ $\left[{ }^{28}\right]$.

По проекту переработки Алексинацких сланцев в СФРЮ для производства 1,22 млн. $т$ ИЖТ в год по ценам 1981 г. требуется 650 млн. долларов, а прямые расходы составляют 51,5 долларов на тонну ИЖТ [19].

Цифровые данные, встречающиеся в источниках литературы в других единицах измерения, в нашей статье переведены следующим образом:

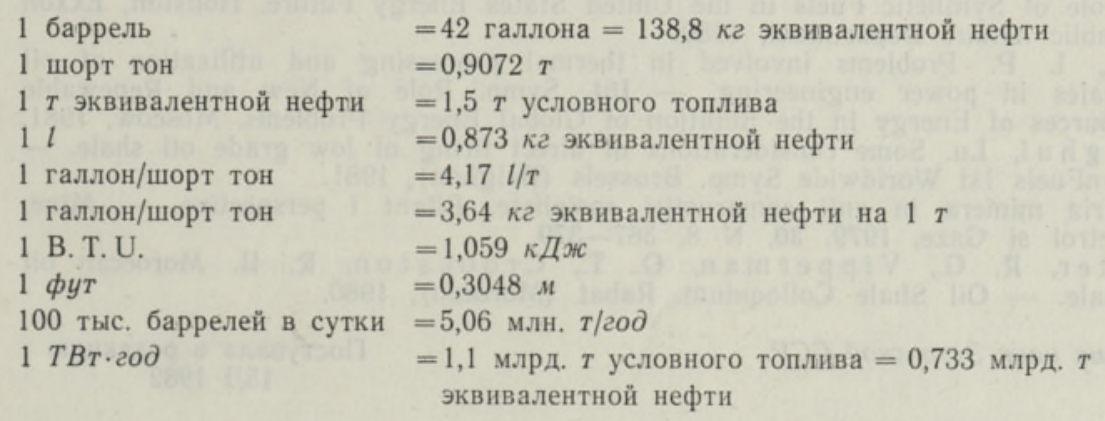

\section{ЛИТЕРА Т Р А}

1. Häfele, W. Energy in a finite world. IIASA Executive Report 4, written by A. McDonald. Laxenburg (Austria), 1981.

2. Delahaye, C. IIASA survey on world oil-shale resources estimated. - 6th IIASA Res. Conf. Golden (USA), 1981.

3. Astakhov, A., Kolosov, A. Oil shales of the USSR and recent situation with their mining. - 6th IIASA Res. Conf. Golden (USA), 1981. 
4. Hellestam, S. Oil shale in Sweden. - Gasification for production of synfuels. - 6th IIASA Res. Conf. Golden (USA), 1981.

5. Southern Pacific Petroleum N. L. 1980 Annual Report. Sydney, 1981.

6. Н а л и П. Нефть из сланцев - перспективы на 80-е годы. - Америка, 1980, октябрь, № 287.

7. Thompson, B. N. Some oil shale deposits in New Zealand. - 6th IIASA Res. Conf. Golden (USA), 1981.

8. Bouchta, R., Berrada, S. Development of T3-process in Marocco, presented by C. Y. Cha and U-Sun Park, Science Applications, Inc. USA, - 6th IIASA Res. Conf. Golden (USA), 1981.

9. Hail, R. O. Utilization of oil shale fines and retort product gas for power generation and $\mathrm{SO}_{2}$ emission control, presented by U-Sun Park and C. Y. Cha, Science Applications, Inc. USA. - 6th IIASA Res. Conf. Golden (USA), 1981.

10. T a mm, P. W., Bertelsen, C. A., Handel, G. M., Spars, B. G., W a $11 \mathrm{~m}$ a n, P. H. The Chevron STB Oil Shale Retort. Washington, 1981.

11. Decora, A., Freitas, I. Report of the technical panel on oil shale and tar sands. - UH Conf. on New and Renewable Sources of Energy. New York, 1980.

12. Dermott, W. F. Development of a commercial oil shale project. - 6th IIASA Res. Conf. Golden (USA), 1981.

13. Прогноз горючих сланцев Европейской части СССР. Таллин, 1974.

14. Meyer, R. Western states energy resources development. - Mines Magazine, 1981,71 , June, N 6 .

15. Petty, Patricia C. Oil shale - tomorrow's answer. - Mines Magazine, 1981, 71 , June, N 6.

16. Iva nac, J. F., Turner, John S. Planning for commercial development. 6th IIASA Res. Conf. Golden (USA), 1981.

17. Andrianasolo, H. R. Oil shales of Bemolanga and their impact on the national economy of Madagascar. - 6th IIASA Res. Gonf. Golden (USA), 1981.

18. Bouchata, R., Marcil, A. Maroccan oil shale development program, presented by G. French and L. Cerrillo, Science Applications, Inc. USA. 6th IIASA Res. Conf. Golden (USA), 1981.

19. Mijatovic, I., Kapor, B. Oil shale inclined modified-in-situ retorting in Aleksinac basin, Yugoslavia Development Program, presented by G. French and C. Y. Cha, Science Applications, Inc. USA. - 6th IIASA Res. Conf., Golden (USA), 1981.

20. Matsui, K. World energy outlook and role of liquid fuel. - 6th IIASA Res. Conf., Golden (USA), 1981.

21. Warren, P., Loehr, W. Colorado oil shale development scenarios, 19812000, - 6th IIASA Res. Conf. Golden (USA), 1981.

22. Bryson, A., Good, Linda, Gust af s on, R., Hughes, M., Neville, A., Reagan, T., Robinson, V. Electrical demand by the oil shale industry: can it be met? - Mines Magazine, 1981, 71, June, N 6 .

23. Hecox, W. E. Energy and natural resource management techniques in Northwest Colorado. - 6th IIASA Res. Conf. Golden (USA), 1981.

24. The Role of Synthetic Fuels in the United States Energy Future. Houston, Exxon Public Affairs Department, 1980.

25. Opik, I. P. Problems involved in thermal processing and utilization of oil shales in power engineering. - Int. Symp. Role of New and Renewable Sources of Energy in the Solution of Global Energy Problems, Moscow, 1981.

26. Lianghui, Lu. Some considerations of direct firing of low grade oil shale. SynFuels 1st Worldwide Symp. Brussels (Belgium), 1981.

27. Industria miniera in anii constructiei socialiste. Bilant $\mathrm{i}$ perspective. - Mine, Petrol si Gaze, 1979, 30, N 8, 367-379.

28. Vawter, R. G., Vipperman, O. T., Crookston, R. B. Moroccan oil shale. - Oil Shale Colloquium. Rabat' (Morocco), 1980.

Академия наук Эстонской ССР

Поступила в редакцию $15 / \mathrm{I} 1982$ 


\section{MAAILMA POLEVKIVIVARUDEST JA NENDE KASUTAMISEST VÄLISRIIKIDES}

On toodud andmeid 33 riigi põlevkivivarude kohta, mis õlisaagiseks arvestatuna moodustab 630 miljardit tonni vedelkütust. Vähemalt 12 riigis tegeldakse põlevkivi kasutamise projektidega. Artiklis on iseloomustatud tööstuslikke ja pooltööstuslikke katseseadmeid vedelkütuse saamiseks põlevkivi termilise töötlemise teel ja antud ülevaade tähtsamatest välismaistest projektidest põlevkivi kasutamise kohta vedelkütuse ja elektrienergia saamiseks.

\section{OPIK}

\section{STATUS OF OIL SHALE WORLD RESOURCES AND MAJOR PROJECTS OF THEIR DEVELOPMENT}

The known oil shale resources and/or reserves in 33 countries by up to date information (1981) amount to a total of 630 milliard metric tons of crude oil, estimated by Fischer's assay. The status of 20 major oil shale projects in the USA, Brazil, Morocco, Australia, Yugoslavia, Sweden and China, with a summary crude oil production of 60 million $t$ a year by a thermal treatment of approximately 700 million $t$ of oil shale is described.

There are also projects of burning oil shale for electric power generation in the USSR, Romania, Morocco and Jordan with a summary demand of ca 70-100 million $\mathrm{t}$ a year. 